\begin{tabular}{|c|c|c|}
\hline & 説 & Review \\
\hline
\end{tabular}

\title{
肌の生化学的パラメーターと肌状態および スキンケア化粧品の有用性評価†
}

\author{
山村 達 郎 \\ 株式会社ノエビア 製品研究所垶
}

\begin{abstract}
肌の表面状態は表皮の角化過程に大きく影響される。そのため, 肌状態を正確に評価するためには表 面の物理的なパラメーターだけでなく，表皮のターンオーバーを反映している生化学的なパラメーター についても測定する必要がある。皮膚表面の角質細胞の形状, 有核率, 剥離密度, 細胞面積, 多重剥離 度は，表皮の角化過程を判断するのに非常に有用である。また，角質層のプロテアーゼ活性や過酸化物 消去能も表皮のターンオーバーを反映している。これらの生化学的なパラメーターと皮膚表面水分量, 皮脂量, TEWL 值等の物理的パラメーターを組み合わせることにより, 肌状態を細かく分類すること が可能となった。
\end{abstract}

\section{1. は じめに}

肌の状態を客観的に評価することは，スキント ラブルの原因を究明したり, 化粧品の有用性を調 べる上で非常に重要である。肌の柔軟性や外観の 美しさは, 皮䖉表面の水分量や皮脂量に大きく影 響されている。そこで，一般的に肌状態は皮膚表 面の物理的な性質, すなわち, 水分量, 皮脂量, 経表皮水分損失（TEWL）などで評価されている。 しかしながら，皮膚の細胞はターンオーバーによ って常に入れ替わっているため，これら表面から の情報だけでなく, 表皮の内部的な情報を反映し ている生化学的なパラメーターを調べることによ って，肌の状態をより正確に評価することが可能 になると考えられる。

ここでは，表皮のターンオーバーを反映してい るプロテアーゼ活性や角質細胞形態, ならびに, フリーラジカルによるダメージから肌を保護する 指標となる過酸化物消去能について皮膚の表面状 態との関係を述べる。また, これら生化学的なパ

$\dagger^{1}$ 1998. 3. 16 受理

$\dagger^{2}$ 个527-8588 滋賀県八日市市岡田町 112-1:112-1,

Okada-cho, Yokaichi, Shiga 527-8588, Japan
ラメーターを用いたスキンケア化粧品の有用性評 価の応用についても紹介する。

\section{2. 肌の生化学的パラメーター}

肌の生化学的なパラメーターとして，よく用い られているのが角質細胞の形態観察である。角質 細胞には，表皮層での分化（角化）の状態が良く 反映されており，表皮内部の様子を知る手がかり となる。また, 最近では角質細胞の剥離にプロテ アーゼが関与しているとの報告があり，ターンオ 一バーとの関係が注目されている。一方, 我々は フリーラジカルによるダメージから肌を保護する 指標として測定した過酸化物消去能について, 肌 状態と関係があることを見いだした。以下に，こ れら肌の生化学的パラメーターについて簡単に述 べる。

\section{1 角質細胞形態}

角質層は死んだ細胞の集まりであるが，その細 胞形態には表皮における角化の状態が良く反映さ れている。すなわち, 正常な肌では角質細胞は五 角形もしくは六角形で互いに接触しており，いわ ゆる敷石状に配列している。また，核などの細胞 内器官は完全に消化されており, 細胞内部は均一 
である。肌荒れなどでターンオーバーが乱れると 表皮の角化が正常に行われず，角質細胞の形態に 変化が現れる。

角質細胞は, 肌に押し当てたカップに Triton X100 を含んだ緩衝液を入れて摚抖し, 剥離した角 質細胞を採取したり口, セロファンテープや粘着 剤を塗布したスライドガラスを肌に押し当てるこ とによって採取される2゙。採取した角質細胞は染 色後, 顕微鏡での観察や画像解析を行うことによ $り$, 角質細胞の形状, 配列, 細胞面積, 有核細胞 数, 剥離度合いなどの項目で評価されている ${ }^{3)} 。$

通常, ターンオーバー速度が速くなると細胞面 積は小さくなる1”また，不全角化が起こると細 胞内に核やその痕跡が残り, いわゆる有核細胞が 多く見られる。肌荒れした角質細胞では細胞の配 列が乱れ, 形状も様々に変化して数層の細胞が不 規則に重なって剥離する様子が観察される。

\section{2 プロテアーゼ活性}

皮膚表面からの角質細胞の剥離メカニズムにつ いては，まだ完全に明らかにされたわけではない が, 最近, 角質層中にプロテアーゼが存在するこ とが報告されており が注目されている。角質層における細胞同士の接 着因子として以前から細胞間脂質が取り上げられ てきたが5),6)，最近では角質層においてもデスモ ゾームが細胞の接着に関与している可能性が示さ れている7。このデスモゾームが角質層最外層で プロテアーゼによって消化されることにより，角 質細胞の剥離がコントロールされているのである。

角質層に存在するプロテアーゼはトリプシンの 基質に対して特異的に作用し，セリンプロテアー ゼやトリプシン様プロテアーゼの阻害剤で, その 活性が抑制されること, $\mathrm{pH} 8 \sim 9,37^{\circ} \mathrm{C}$ 付近で最 も活性が高いことが報告されている8)。また, 数 種類のセリンプロテアーゼが存在している可能性 や，角質層内部よりも表層で活性が高く（Fig.1), 角質層を円柱状に切り取りアロンアルファ で固定した場合, 角質層からは細胞の剥離が容易 に起こり、角質層深部を外側にした場合には殆ど 剥離が起こらない (Fig.-2) ことなども示され ている9。っさらに, SLS で肌荒れさせた場合には

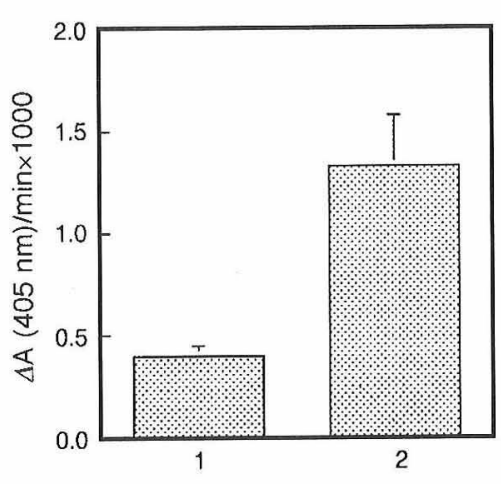

Fig.-1 角質層のプロテアーゼ活性 1 : 角質層深部, 2 : 角質層表面 $(n=6, p<0.01)$

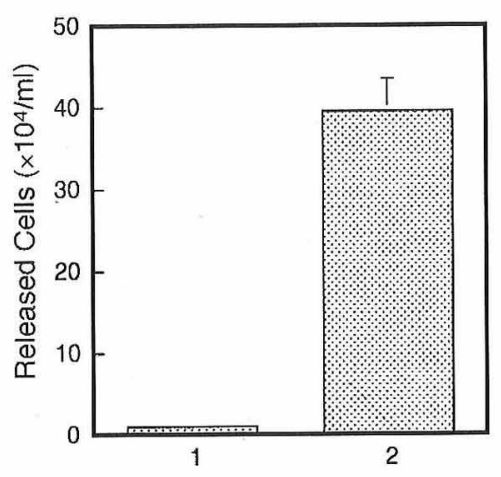

Fig.-2 足底角層シリンダーからの細胞剥離 1 : 角層深部加の剥離, 2 :角層表面 からの剥離 $(n=7, p<0.01)$

プロテアーゼ活性が有意に高くなることが示され ており ${ }^{10)}$, 肌状態やターンオーバーと関係が深い ことも予想される。

角質層のプロテアーゼ活性の測定方法の一例を Fig. $-3 に$ にした。テープストリッピング法で採 取した角質細胞に基質として peptidyl 4methylcoumary1-7-amides（Boc-Phe-Ala-MCA）を 加え, $37^{\circ} \mathrm{C}$ で $20 \mathrm{~min}$ 反応させたときの生成した 7-amino-4-methylcoumarin(AMC) 量からプロテア 一ゼ活性の強さを比較することができる8)。

\section{3 過酸化物消去能}

皮膚表面には皮脂など酸化されやすい物質が存 在しており，紫外線などで生じるフリーラジカル の作用で過酸化物が生成しやすいことが予想され ている。実際, 過酸化物は皮䖉に有害であり, 肌 


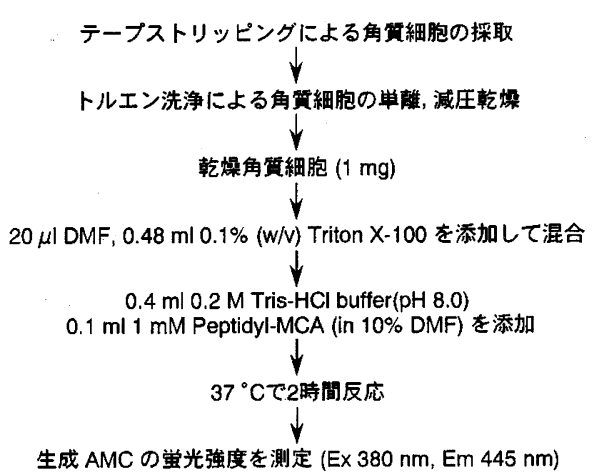

Fig. - 3 角質層プロテアーゼ活性測定法

状態を悪化させたり老化の引き金になることが知 られている(1)。このような酸化ストレスに対して， 皮膚には過酸化物の生成を防ぐ物質も存在するこ とが確認されている。そこで我々は角質細胞の過 酸化物消去能を Fig. -4 に示した方法で測定して， 肌状態を示す他のパラメータとの関係を調べた。

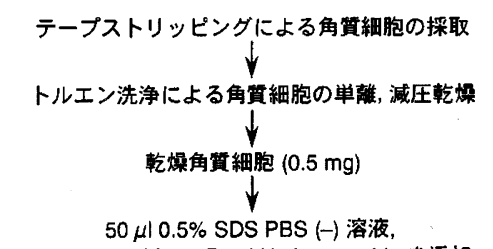

$50 \mu \mid 380 \mu \mathrm{M}$ tert-Butyl Hydroperoxide を添加

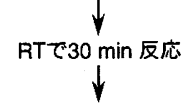

$160 \mu \mathrm{l}$ PBS (-), $100 \mu \mathrm{l} 32 \mu \mathrm{M}$ Dihydrorhodamine 123 , 65.7 units/ml Peroxidase を添加

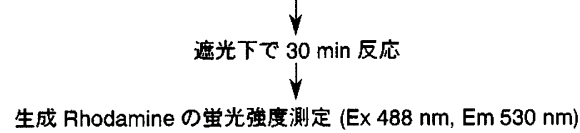

Fig. -4 角質層過酸化物消去能測定法

角質細胞の過酸化物消去能と肌状態の間には相 関関係が見られ，特に，過酸化物消去能が低下す るとともに TEWL 值が上昇したり (Fig.-5)， 角質細胞面積が小さくなる (Fig. -6) ことが認 められた。このことから，皮膚表面の過酸化物の 生成が角質層のバリヤー機能を低下させることに より，表皮のターンオーバーに影響を及ほしてい ることが予想された。

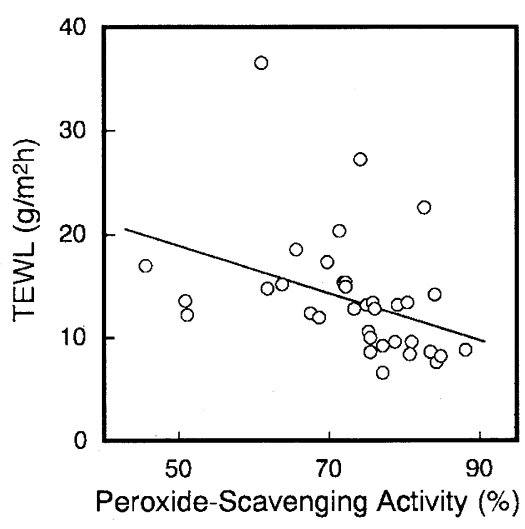

Fig. -5 角質層の過酸化物消去能と TEWL 值の相関関係 $(r=0.374, p<0.02)$

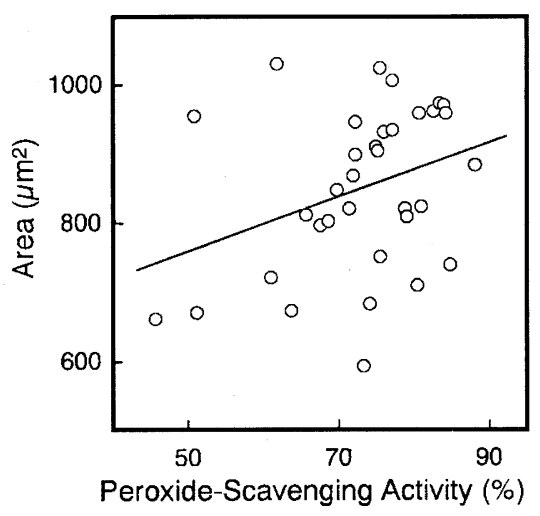

Fig. -6 角質層の過酸化物消去能と角質細胞面 積の相関関係 $(r=0.340, p<0.05)$

3. 肌状態と生化学的なパラメーター

肌状態に影響を及ぼす最も大きな因子は角質層 に含まれる水分である。肌の水分量は，角質層の バリヤー機能と水分保持能で調節されているが, これらの機能の発現に重要な役割をしているのが 角質層の細胞間脂質と自然保湿因子 (NMF) で ある。表皮のターンオーバーに異常が発生すると 正常なバリヤー機能や水分保持能が形成されず, 肌は乾燥して状態が悪くなる。したがって，肌の 状態を的確に評価するためには，皮膚表面の物理 的な性質に加えて表皮のターンオーバーを反映し ている生化学的なパラメーターが重要な役割を果 たす。 
3.1 表皮ターンオーバーと生化学的パラメー ター

肌に薬剂を塗布したり紫外線を照射するなどの 刺激を与えると，表皮のターンオーバーは変化す ることが知られている。たとえば，表皮のターン オーバー速度を速めることが知られている $n^{\text {オへ }}$ キサデカンをヘアレスマウス背部に塗布した場合 には，TEWLの上昇と鱗首をともなう肌荒れを 生じる。このときの皮膚組織を観察すると表皮は 正常時の約 3 倍に肥厚しており (Fig. - 7), 顆粒 層から角質層にかけて角化異常が見られる。また, 角質細胞形態では有核細胞数の増加, 形態の乱れ, 細胞面積の減少, 多重剥離などが観察される。

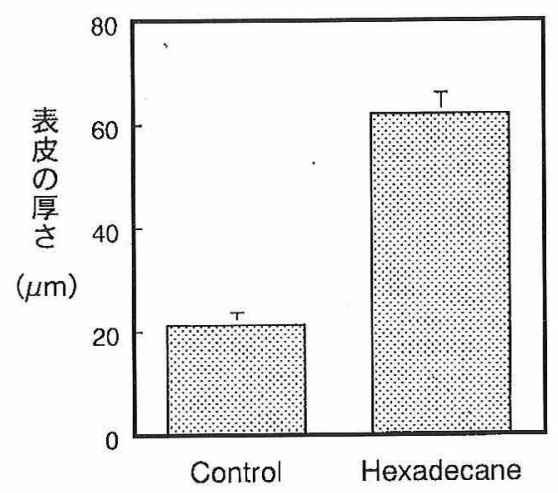

Fig. 7 n-ヘキサデカン塗布による表皮厚の変化

肌荒れした状態でのプロテアーゼ活性は, $n^{-}$ ヘキサデカンを塗布していない場合に比べて明ら かに上昇していることが確認された（Fig.-8）。 このことから, 表皮のターンオーバー速度が速く なるとともに，角質層のプロテアーゼ活性も高く なると考えられる。

\section{2 肌状態の分類}

肌状態の分類にはいくつかの方法があるが，こ こでは, 角質層のバリヤー機能と水分保持能に着 目した肌状態の分類方法について紹介する。皮虚 表面の水分量, 皮脂量, TEWL 值ならびに角質 細胞の形態, 有核細胞数, 剥離密度, 細胞面積, 多重剥離度を目視によるスコア化ならびに画像解 析による定量化を行い主成分分析を行うと, 総合 的な水分保持能を表す第 1 軸と角質細胞の形態や

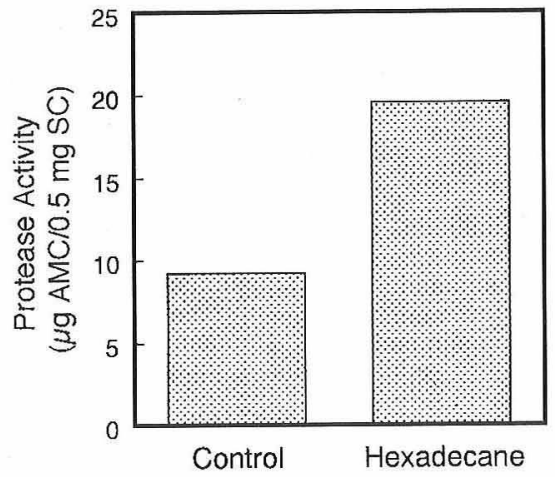

Fig.-8 n-ヘキサデカン塗布によるプロテ アーゼ活性の変化

配列に関係する第 2 軸が得られる。さらにここの 主成分プロットをクラスター分析を行うことによ り，Fig. $-9 に$ 示した四つの特徽を持った肌状態 に分類することができる。

このようにして得られたそれぞれのクラスター は，角質層のバリヤー機能や水分保持能ならびに 表皮の夕ーンオーバーの状態を反映しており，ス キントラブルの原因を調べたり，スキンケア化粧 品の有用性を評価するのに適している。

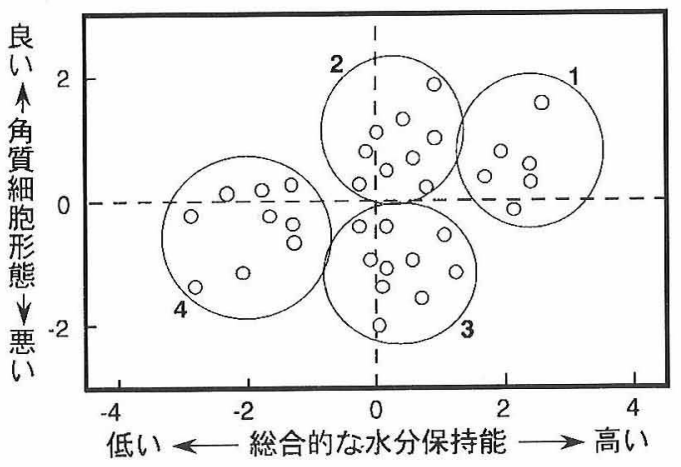

Fig. -9 主成分分析による肌状態のクラスター 分類

1: 表皮夕ーンオーバーが正常で良好 な状態

2：水分保持能が低下して乾燥しやす w状態

3：角質細胞の接着性が弱まっている 状態

4：肌荒れしてターンオーバーが乱れ た状態 


\section{3 肌状態と生化学的パラメーター}

3.2 で示したそれぞれの肌状態における, 角質 層のプロテアーゼ活性と過酸化物消去能を Fig.10ならびに Fig.-11に示した。プロテアーゼ活性 は肌状態の良好な第 1 クラスターで最も低い值を 示し，肌の状態が悪くなるにしたがって，次第に 高くなった。反対に過酸化物消去能は肌状態の良 好な第 1 クラスターで最も高い值を示し，肌状態 が悪くなるとともに低い值を示す傾向が認められ た。したがって，状態の悪い肌では表皮のターン オーバーが速くなるため正常な角質層が形成され ず，バリヤー機能や水分保持能が低下したり，角 質細胞の剥離がスムーズに行われなくなると考え られた。また，紫外線やフリーラジカルの作用に より生じる過酸化物によるダメージも受けやすい ことが予想された。

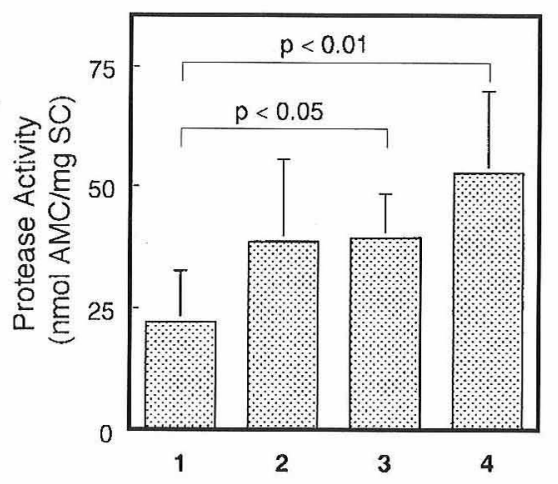

Fig. -10 肌状態（クラスター）と角質層プロテ アーゼ活性

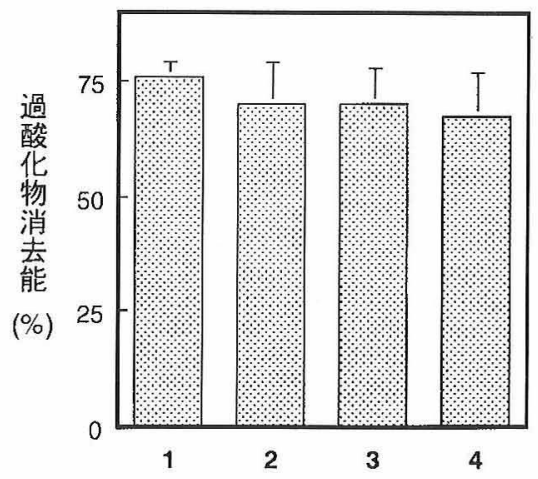

Fig. -11 肌状態（クラスター） と角質層過酸化 物消去能

\section{4. スキンケア化粧品の有用性評価}

スキンケアの目的は美しくみずみずしい肌を保 つことであり，化粧品においても角質層への水分 補給や水分保持力を高めるような処方設計がされ ている。しかし, 皮虐表面の水分量が適度に保た れた場合には肌状態が改善され，表皮のターンオ ーバーも正常なサイクルに戻ることが予想される。 したがって，皮膚表面の物理的なパラメーターた けでなく生化学的なパラメーターを用いてスキン ケア化粧品や有効成分の効果を評価することによ り，肌状態におよぼす影響をより詳細にとらえる ことが可能になると考えられる。

\section{1 尿素ローションの肌荒れ改善効果}

尿素は保湿効果の高い薬剤であり，ハンドクリ ームやひじ・かかとの固くなった角質層を柔らか くするクリーム等に配合されている。1\%尿素口 ーションを 1 カ月間使用した場合の肌状態の変化 を皮膚表面の物理的なパラメーターと角質細胞形 態, プロテアーゼ活性を用いて評価した。

尿素ローション使用前後では, 皮膚表面の水分 量, 皮脂量, TEWL 值に大きな変化は見られな かったが，角質細胞の形態には変化が見られ，細 胞形態，剥離密度，有核細胞数より算出した形態 スコアは使用後で高い值を示し（Fig.-12）, 細胞 面積は大きく (Fig.-13), 多重剥離度は低い值を

(Fig. -14）示していた。

また, 使用前後の肌状態を 3.2 で示したグラフ にプロットしてみると，総合的な水分保持能には 変化は見られないものの角質細胞の形態が改善さ れており，表皮のターンオーバーが正常にもどっ ていることが示されている（Fig.-15）。

\section{2 ドライスキンに対する美容液の効果}

ドライアイスを用いた冷風を顔面に長時間当て ることにより，ドライスキンを誘発することがで きる。1 週間冷風を当てることにより生じたドラ イスキン部位に，リン脂質とアミノ酸を配合した 美容液やグリセリン水溶液を 1 週間塗布したとき の肌状態をTable-1に示した。

リン脂質とプロリンやイソロイシンなどのアミ ノ酸を組み合わせた場合には，高い閉塞性と優れ 


\section{粧 技 誌第 32 巻 第 2 号 1998}

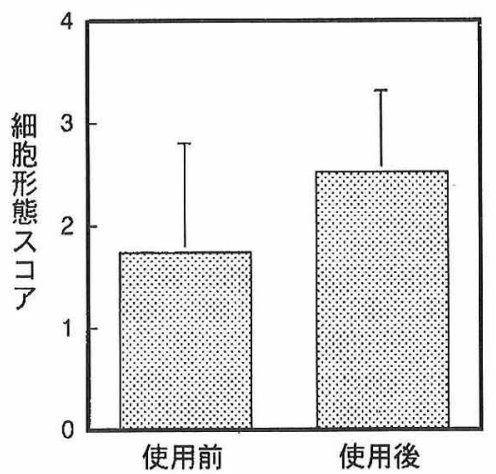

Fig.-12 尿素ローション使用による角質 細胞形態の変化 $(n=7, p<0.05)$

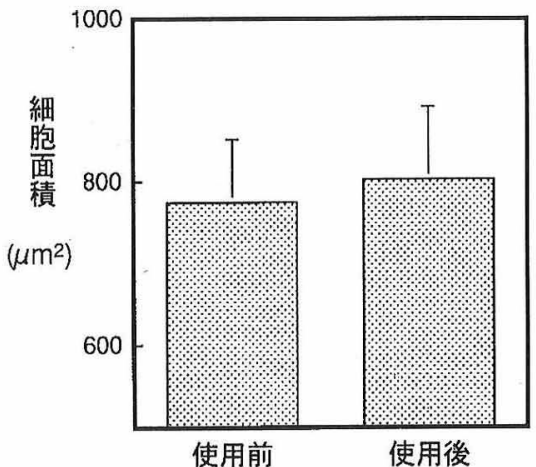

Fig. -13 尿素ローション使用による角質 細胞面積の変化 $(n=7, p<0.1)$

た水分保持作用を示す12)。また，グリセリンには 角質層のデスモゾームの分解を促進する作用があ ることが報告されており ${ }^{13)}$ ，これらはドライスキ ンの改善に有効に作用することが期待できる。 実際，ドライスキンに比べて美容液やグリセリ

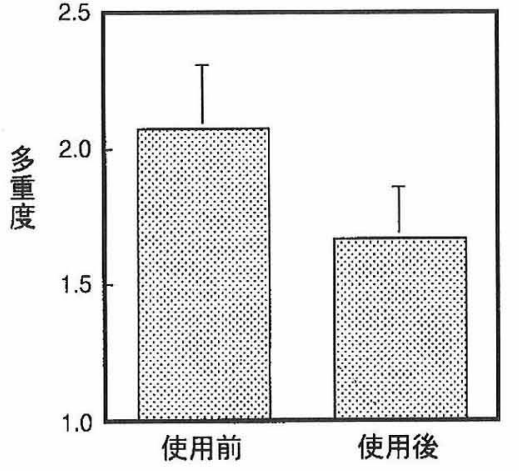

Fig.-14 尿素ローション使用による角質細胞 多重剥離度の変化 $(n=7, p<0.01)$

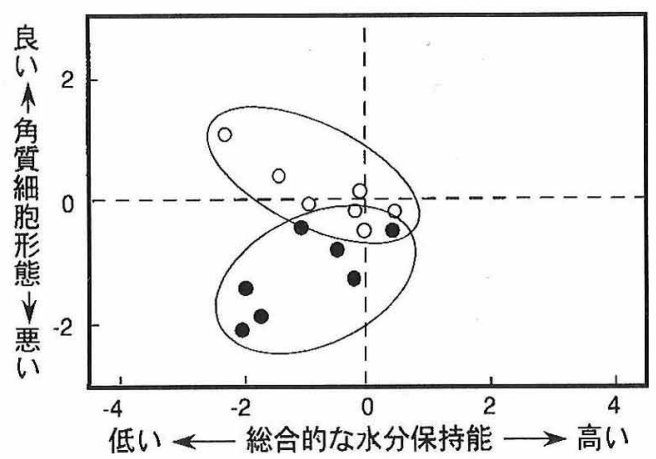

Fig. -15 尿素ローション使用による肌状態の変化 $\bigcirc$ : 使用後, $:$ 使用前

ン水溶液の塗布部位では, 皮虐表面水分量の増加 が観察された。また, 美容液塗布部位では TEWL 值もわずかに低下したが，特に大きな変化は見ら れなかった。しかしながら，プロテアーゼ活性は ドライスキンでは高く, 美容液, グリセリン水溶

Table-1 ドライアイス処理乾燥肌への美容液塗布効果

\begin{tabular}{|c|c|c|c|c|}
\hline 測定部位 & $\begin{array}{l}\text { 水分量 } \\
(\mu \mathrm{S})\end{array}$ & 皮脂量 & $\begin{array}{l}\text { TEWL } \\
\left(\mathrm{g} / \mathrm{m}^{2} \mathrm{~h}\right)\end{array}$ & $\begin{array}{c}\text { Protease activity } \\
\text { (nmol } \mathrm{AMC} / \mathrm{mg} \mathrm{SC})\end{array}$ \\
\hline 㚘頁（Dry skin） & 33.0 & 123 & 35.0 & 18.7 \\
\hline 煩（美溶液） ～～～～ & 102.7 & 139 & 29.0 & 14.9 \\
\hline 煩（グリセリン溶液） & 101.3 & 113 & 32.3 & 15.5 \\
\hline 額（Dry skin） & 118.3 & 150 & 22.0 & 18.9 \\
\hline 額（美溶液） ～～～～ & 228.3 & 133 & 22.8 & 7.1 \\
\hline 額（グリセリン溶液） & 249.7 & 118 & 25.7 & 8.5 \\
\hline
\end{tabular}


液塗布部では明らかに低い值を示した。このこと から，角質層のプロテアーゼ活性の測定は，肌状 態の評価に非常に有効であると考えられた。

\section{5.おわりに}

角質層のバリヤー機能や水分保持能は生体を外 界から保護する機能であると同時に，肌の美しさ を決定する水分量を調節する役割をしている。ま た，これらの角層機能の形成には，表皮細胞が基 底層から有棘層，顆粒層を経て角質層へと角化す る過程で，細胞内で合成される細胞間脂質やアミ ノ酸等の NMF 成分が重要な役割を果たしている。 すなわち，角質層は死んだ細胞の集まりであるが， その形成には表皮のターンオーバーが大きく影響 しているのである。したがって，肌の状態を評価 するためには水分量や皮脂量などの皮膚表面の物 理的な性質だけでなく，表皮のターンオーバーの 状態を調べるための生化学的なアプローチが必要 となる。ここで紹介した角質細胞の形態やプロテ アーゼ活性などの生化学的なパラメーターは表皮 のターンオーバーの様子を反映しており，肌状態 の評価に非常に有用であると考えられる。

\section{引用 文 献}

1）高橋元次, 相沢雅美, 町田靖彦, R. Marks, J. Soc. Cosmet. Chem. Jpn., 20, 194-200 (1986)

2）橿㴊暢夫, J. Soc. Cosmet. Chem. Jpn., 23, 143-154 (1989)

3) E. Holzle, G. Plewig, J. Invest. Dermatol., 68, 350356 (1977)

4) A. Lundström, T. Egelrud, J. Invest. Dermatol., 91, 340-343 (1988)

5) S. Grayson, P. M. Elias, J. Invest. Dermatol., 78, $128-$ 135 (1982)

6) D.T. Downing, M.E. Stewart, J. Invest. Dermatol., 88 , 2s-6s (1987)

7) T. Egelrud, P. Hofer, A. Lundström, Acta DermtoVenereol. (Stockh), 68, 93-97 (1988)

8) Y. Suzuki, J. Nomura, J. Horii, J. Koyama, M. Takahashi, I. Horii, Arch. Dermatol. Res., 285, 372-377 (1993)

9）崔 昌益，高橋昌江，手塚 正，日皮会誌，106, 1393-1396 (1996)

10) Y. Suzuki, J. Nomura, J. Koyama, I. Horii, Arch. Dermatol. Res., 286, 249-253 (1994)

11）宮地良樹, Fragrance J., 25 (4), 17-23 (1997)

12）野口千笑, 山村達郎, 山本泰之, J. Soc. Cosmet. Chem. Jpn., 29, 49-54 (1995)

13) A. Rawlings, C. Harding, A. Watkinson, J. Banks, C. Ackerman, R. Sabin, Arch. Dermatol. Res., 287, 457-464 (1995)

\title{
Biochemical Approach for Diagnosis of Skin Conditions and Evaluation of Skin Care Products $\dagger^{\dagger}$
}

\author{
Tatsuo Yamamura
}

Products Research Laboratories, Noevir Co., Ltd. $\dagger^{2}$

\begin{abstract}
Skin surface conditions are dependent upon the rates of the epidermal proliferation and keratinization. Then, the biochemical parameters influencing the corneocyte turnover rate, as well as the physical parameters of stratum corneum, are important for the evaluation of the skin surface conditions. The morphology of the corneocytes, such as shape, density, nuclear inclusion, area, and multistripping, reflects the rates of epidermal proliferation and keratinization. In addition, the protease activity and the peroxide-scavenging ability of the stratum corneum are related with the corneocyte turnover rate. The skin surface conditions might be classified in detail by the combination of the biochemical properties and the physical properties of the stratum corneum.
\end{abstract}

Key words : skin conditions, keratinization, corneocyte, turnover, stratum corneum, morphology, protease, peroxide-scavenging ability, barrier, water-holding property 